\title{
Making Wayang Along Anthropology and Art
}

\section{Giulia Panfili}

FCSH-Universidade Nova de Lisboa, ISCTE-University Institute of Lisbon, Centro em Rede de Investigação em Antropologia (CRIA)

email: giupanfili@hotmail.it

\begin{abstract}
Practices of art and anthropology are interlacing a dynamic dialog especially for the methodology of research, the process for awakening knowledge. Historically anthropology treated art in its various expressions as privileged field of study for being in a certain way caught up in social and cultural relations. Nowadays more and more the both practices share ways of thinking through making and making through thinking in processes of active going along, engagement with the surroundings and self-discovery. In researching how wayang kulit is being alive in Yogyakarta at the present on going time, art to be intended as creative doing and practical understanding became all in one object, subject and process of the research. Learning by making and performing wayang kulit as well as observing, sharing and discussing with people gives path to experience and question some issues about ways of knowledge and skill transmission; practices of growing between forces, materials and gestures; borders of completion of never-finished objects and practices; relations between practitioners, materials and surroundings; projections of imaginative design between local and global dynamics.
\end{abstract}

Keywords: anthropology and art, making, wayang kulit, liveness

\section{INTRODUCTION}

In this paper I intend to explore the traces that the fieldwork research is leaving along its creative process. This fieldwork experience is part of a $\mathrm{PhD}$ research project that carries the working title "Making wayang in between. Performing cultures with rasa, komunitas, Nusantara and UNESCO". Its utopian aim is to draw/portrait how wayang kulit practices are being alive - in the continuous tension between changing and permanence - at the contemporary on going time in Yogyakarta, and to which extent its practices are being shaped by 2003 UNESCO designation of Indonesian Wayang Puppet Theatre as Masterpiece of Humanity and by related Intangible Cultural Heritage discourses. Similarly Sarah Anaiis Andrieu studied for her doctoral degree the political anthropology of the Sundanese (West Java) wayang golek and its process of patrimonialization, questioning the present and contemporary appropriation of wayang golek (Andrieu 2009).

As several scholars especially in the field of heritage studies widely demonstrated, heritage as well tradition is being made, invented. The heritage formation indeed is a dynamic field of social action with power relations, involving different actors at local, national and global levels (Smith 2006). In her doctoral dissertation 
Sadiah Boonstra also illustrates the dynamics of heritage formation such as standardization, codification and institutionalization from the colonial to the postcolonial era, at national and global levels, as well as the political dynamics at play on wayang (Boonstra 2014). It is to explore anyway how people engage with society, its politics and economy, so how people perform culture and address issues of inclusion and exclusion, in a kind of linkage between the past and the future. In another way and in this specific case, it is to disclose how in the life/ alive experiences, multidimensional relations between puppets, people, stories and places make wayang alive. A concert of many voices, opinions, methods, subjects, perspectives and processes are being taken into account.

For the sake of time and space in this paper I only try to express some resonances of my research. In that intention particularly enlightening has been the reading of Tim Ingold's Making (2013) whose argument is that anthropology, archaeology, art and architecture are ways of thinking through making since making is a correspondence between maker and material. Said another way all four disciplines are linked by the practices of "knowing is movement", an incessant correspondence with the world. It definitely helped to handle with the unavoidable and nevertheless not less unbearable fragmentations of experiences, reflections, sensations, actions and the mores of life, showing a possible way to correspond with it, proposing me one of the threads to pull for untangling the previously created and amassed skein.

\section{Art and anthropology interaction along history}

The relationship between anthropology and art is old. The early anthropologists for long time have investigated and collected together with private collectors and museums the artefacts of often small-scale non-western societies, represented in the western myth of the noble savage. Those far away ethnic groups' objects were referred as primitive art, a controversial term that later was criticized for being based on ethnocentric criteria, therefore replaced by tribal, folk, ethnic and adjectives the more. This previous remoteness between the scholars and their "object of study" was then shortened at the end of the $19^{\text {th }}$ century - beginning of the $20^{\text {th }}$ by the new anthropologist - now an individual fieldwork researcher - which marked the modern phase of the discipline. The encounter with the other and its intensity opened up wider methodological and epistemological issues to discuss. Anthropology have revealed the plurality of cultures and strove to interpret other societies in its own terms and values, distancing evaluative judgements. In the analysis of other cultures' works of art, an ethnographic approach seeking to relate them to their context of cultural meanings and values prevailed. In so doing, the same art definition criteria were challenged.

During the second half of the $20^{\text {th }}$ century the anthropology of art treated art in its various expressions as a privileged field of study for being in a certain way embedded into sociocultural relations and related processes of shaping identity, to be observed and interpreted (Gell 1998). It came that the works of art were mostly treated as finished objects, so analysed in a reverse attribution of meanings 
and intentions. Similar approach can be found in the fields of material and visual culture that mainly focused on the dynamics and interactions that create, use, make circulate and confer values to the objects and images (Appadurai 1986). Notwithstanding the creative, direct, practical and sensuous processes that give rise to art were not contemplated.

In the wake of postmodernity and the "writing culture" critique in the 1980s reflexive or critical anthropology, however, new theoretical frames emerged. The ethnographer authority as well the observer neutrality was criticized for a new understanding of ethnography: no more a ready-made and neutral knowledge rather a creative process that is inescapably based on the experiences of the subject, therefore partial, being one perspective among potentially many (Clifford 1988). That is that the third-person writing was gradually replaced by the firstperson. This new theoretical frames were not only auto-reflexive, anthropologist's navel-oriented, it goes that in parallel anthropologists redesign the position and approach with the object of study, if of the object of study it is still possible to talk. The growing and renewed attention paid to the subjective dimension in the engagement with the surroundings paved the way for a kind of reawaken of senses as is reflected in the contemporary anthropology of emotions. The relative dimension of the experience highlighted the importance to be aware of the particular space and time in which the experience itself happens. Its dynamicity and in a certain way its elusiveness for being in constant changes are now highlighted. Cultural processes, practices, actions and changes are questioned in the field of anthropology of performance (Schechner 2002) and in the wake of autocriticism the definition of the other itself were questioned. The fieldwork was redesigned to include together with the classical small-scale non-western societies also metropolis, urban communities, the researcher him/herself. New disciplines such as anthropology of complexity and urban anthropology arose and what was until now considered objects and subjects blurred.

Back to the art, keeping in mind what has been shortly described above, it can be understandable in which directions can be recently traced a dynamic dialog between art and anthropology. Increased attention is paid to individual artists and their processes of creativity. New life is conferred to the previous deadobjects through the movements of nouvelle museology and critical museology. Anthropologists are exploring new forms of research and representation beyond written texts: the so-called visual anthropology offers some examples of the wide possibility to link research methods and visual representation between anthropology and art through drawing, photography, video, digital media and so on (Banks and Morphy 1997; MacDougall 1998; Grimshaw 2001; Pink 2004). Since early the drawings, then the photographs and later the videos, were first used for illustrative purposes as accompaniment of the words, then - given the reconfiguration of ethnographic strategies - take a role no longer merely auxiliary but as one of the research and questioning media of anthropology, as illustrated by the pioneering work of Margareth Mead and Gregory Bateson in Bali on 1942. 
On the other hand, following the so-called "ethnographic turn", contemporary artists have adopted an "anthropological" gaze and methodologies such as fieldwork and observant participation or appropriation of the archive of the memory (Enwezor 2008). Collaborations between anthropologists and artists have been few (Schneider and Wright 2006, 2010) nevertheless art and anthropology nowadays more and more share their practices, their ways of thinking through making and making through thinking in processes of active going along, engagement with the surroundings and self-discovery.

Most illustrative examples however are found in the field of art. "Born into brothels: Calcutta's Red Light Kids" (2004) an Indian-American documentary film about the children of prostitutes in Sonagachi, Kolkata's red light district directed by Zana Briski is based on the increasingly common technique in visual anthropology to give informants cameras. In so doing photography and video are both recording device and research tool. In 2014 a young Argentinian-born artist called Amalia Ulman used her Instagram and Facebook profile for staging a five months elaborate online performance called Excellences $\mathcal{E}$ Perfections. Selfies taken on her iPhone became one of the most original artworks of the digital era, shown in Tate Modern's "Performing for the Camera", which examine the relationship between art performance and photography, and at the same time it could be perfectly an ethnography.

Finally, another type of collaboration can make us reflect in general on disciplines and fields of knowledge as well as on art as a catalyst for investment today: the European Organization for Nuclear Research CERN provides artist residencies and research at its laboratory with the conviction that "particle physics and the arts are inextricably linked: both are ways to explore our existence, what it is to be human and our place in the universe. The two fields are natural creative partners for innovation, research and development" (http://arts.cern/home).

\section{Fieldworking}

"Remind, this is a PhD in anthropology not in art" - my lecturer's advice is still resonating in me. At that time, sitting in the seminar room at the university, although surprised by the direct recommendation to respect the boundaries between disciplines, I felt prepared to receive it being in a certain way already aware of the institutional codes and pretending to know where those moreover fictitious margins resides. Anyway once in the fieldwork it happened the inevitable: art and anthropology correspond to each other and blurred. Its unavoidability was due to the encounter itself between the student carrying on this $\mathrm{PhD}$ research project - a not irrelevant aspect if considering the reflexive turn in anthropology - and the fieldwork. She is a nearly 30 years old Italian, cultural anthropology student, traveller and art practitioner. The field of research is wayang kulit liveness in Yogyakarta and despite its polysemy does not leave to be stressed, in several situations wayang is considered seni (art) as well as its performers seniman (artists). 
Along the encounter or the negotiation that as anthropology student I was expected to pretend, I realized the difficulties to fully explain - or be understood, depending on the angle - the reasons for my presence or rather the research objectives. It seemed as if on one side each one of my interlocutors pulled toward his or her nearest conceivable experience the reasons for me to be there and as though on the other side I feed these understandings since my actions imitate their own. After some attempts I went to the game, so the chameleon performance has begun. As I am learning in practice how to make and perform wayang kulit, suddenly I became an aspiring puppeteer or possibly a singer in the midst of puppetry students - "Mau jadi apa? Dalang atau sinden?" - and an artist or artisan even with some previous mastery as already at the doctorate - "sudah S3!" - in the middle of puppet-makers students.

Since my arrival in Indonesia on July 2015 I was told that "for being a dalang take much imagination, for that art especially if heart and mind are not fused it would be difficult. On the contrary if heart and mind are already merged and pleased observing continuously and practicing, after time you will be able to" (from a short talk with Bapak Sumardi, coordinator of Museum Wayang at Jakarta and also dalang, puppeteer).

Key words such as menyatu (becoming one) and pake rasa, senang dulu (with feelings, enjoy it first) are repeated several times and actually they are practiced too. Observing, listening, feeling and doing became mainly the learning process. That is for learning both how to make and perform wayang kulit puppets, after a brief demonstration if any, I was soon sat up in front of the leather, tools in the hands.

I had the privilege to attend carving and coloring (tatah sungging) class from the State Academy of Art and Culture Community Yogyakarta (Akademi Komunitas Negeri Seni Budaya Yogyakarta AKNSBY) held at Mr. Sagio studio (Griya Bapak Sagio), in Gendeng village, Bantul. These weekly three days classes are part of the one year Experts Primary Education Program, a joint program between the Yogyakarta Regional Government (Daerah Istimewa Yogyakarta DIY) and Institut Seni Indonesia ISI. Already at its second edition, this program is funded by the Yogyakarta Regional Government and can be only attended by Yogyakarta residents. Its purpose is to train puppet makers as well as dancers and gamelan players who once passed the final exam according to the contract should work for Desa Budaya (Culture) or Wisata (Tourism), villages in DIY.

For learning how to perform wayang kulit, I have followed the first semester of theoretical and practical course of puppetry (pedalangan) at Institut Seni Indonesia ISI Yogyakarta University. After that, I enrolled in the puppetry evening course at the sultan palace (kraton) traditional school (sanggar) named Habirandha. As the performance involves music, vocal technique, Javanese language and the more, I am joining the basic singing and vocal technique (macapat) course at sanggar Hadiningrat, another traditional school of the kraton and I am having private lessons of Javanese language. 
With time, making and performing wayang kulit as well as observing, sharing and discussing with people gives path to a personal deeper understanding of Javanese wayang kulit. By Making's revelatory reading I realized that my fieldwork could correspond with what Tim Ingold experienced at his early career and later stressed, namely that "the only way one can really know things - that is, from the very inside of one's being - is through a process of self-discovery. To know things you have to grow into them, and let them grow in you, so that they become a part of who you are" (Ingold 2013: 1). Studying with people, being involved in their activities, learning by doing lately reconfigured the fieldwork or rather the researching process. Learning revealed itself to be a personal inner understanding in practice, not an already made package of knowledge to acquire.

In his thesis that "making is a correspondence between maker and material" Ingold argued that the material is alive and that the maker intervenes in worldly processes that are already going on. That is making is a practice of growing between forces, materials and gestures. Working with leather it is vividly confirmed. Leather from goat, cow and buffalo - in order from the least to the highest quality - is used for making wayang kulit. Therefore as part of animals, the leather undergoes a particular process for being transformed into parchment. "The parchment should not take neither light nor water" the man who treat and prepare the raw leather ready to be cut and curved, advised me. I was probably not yet aware of tropical weather consequences and part of the leather I bought for making wayang became an abstract painting while I was away for a while for the Christmas holiday. Visibly other forces such as humidity, fungi and insects preceded me into the process of giving form to leather to become possibly wayang.

Making, giving form to things, arises through movement, the dynamic properties of materials and the balance of the forces at work. Indeed the leather is carefully carved with wood gavel beating metal spikes whose ends are previously sharpened against a whetstone (batu asah). To avoid that the spikes ends are broken the leather is leaned on a log of sawo wood (manilkara zapota, commonly known as sapodilla) the consistency of which dampens the hits. At the same time the leather remains stable thanks to a weight whose top moreover is covered by wax in which systematically the spikes ends are rubbed in order to impart more slipperiness. The puppet maker sat at the table, the right hand rhythmically hit with the gavel while the left hand guides the spikes on the leather. In act, there is a mutual correspondence between the maker and the material. In this kind of empathy the maker mood is especially involved in the creation of the puppet character. The master maker Bapak Sagio revealed that he used to spend one week for his own preparation for making a new character. He needs to feel and behave as the puppet would feel and behave. Nowadays a drawing photocopy or another existing puppet is used as pattern for new creations. Anyway each one is still different, reflecting the mood and temperament of its maker as well as the surroundings circumstances. 
In practice together with my companions I learned that the leather is not all of the same thickness, therefore the more the puppets are small and graceful more the leather should be thinner, vice versa the more the puppets are big in size more the leather is thick. It happened to me to make a seemingly graceful and delicate female puppet, that however once removed from the flat surface it bent, it could not stand. So I realized that also the single puppet requires the thickest part of the leather to its base at the foot and the thinnest at the head. I could realize that only performing and manipulating the puppets. Once again only performing I could understand the importance of the puppets sizes as they seem to be reached and established for a comfortable handling.

In this progression of making and learning another issue was opened up that is if there is any point of completion establishing when the puppets is finished. Ie making the puppets corresponds to what will be their function and somehow it is uncertain to affirm when the process is complete. Nevertheless of course takes a different direction, different performative ways, this problematic exists even in the case of puppets made for decoration, collection or touristic souvenirs to be exhibited on the wall or in any other way. In fact puppets made for these purposes require attention and care for their maintenance such as for example the white gloves of the museum conservator or the ritual pusaka (heirloom) cleansing at the kraton (sultan palace). It seems to be puppets are rather never-finished objects, continuously in movement, alive. According to Jan Mrazék "it is fruitful to discuss visual and performing arts together because in Indonesia they are indivisible in their world" (Mrazék 2008: 292-293). Objects are practices.

The coloration given to the puppets allows and helps the puppeteer to empathize more with the character that he or she is performing - moving, giving voice and making alive. Performing we look at the puppets, especially the face, and when there is action especially battle which is rapid the colours help to quickly identify the key parts of the body. That is a reason for reading from book is not so helpful. Other reason is that do not train memory for memorize the stories and the dialogues, so even the improvisation becomes more difficult

Finally as can be seen learning in practice and sharing activities allow me not only to know wayang kulit from the inside but also to experience and question how wayang knowledge and skills are transmitted. Actually its transmission can occur through family tradition and inheritance, informal learning at local sanggar (studio), governmental initiatives namely vocational high schools, graduate programs and specific courses and also as autodidact mostly with the help of video recordings. As earlier pointed out the first appreciated approach to wayang is a full involvement by feelings (rasa), to be interpreted however not only literally and innocently inasmuch patterns to follow are provided. Indeed these models are a source of discussion for the next generations since both in making and performing wayang by some is considered to affect the dimension of improvisation and creativity while by some others is highly recommended in order to secure the local style. 
Taking part of the wayang kulit liveness at Yogyakarta, it was possible to meet and share with people differently related to it: lecturers and teachers, students and lovers, puppeteers and scholars, artisans and artists, association members and politic representatives. In the middle of those relations (or lack of relations) and their discourses became evident what anthropologists and other social scientists remarked that culture is also politics.

Despite the research inevitably has led to other regions as well, Daerah Istimewa Yogyakarta DIY constitutes the main place where the until now one year fieldwork focused. Its scenario shows itself to be particularly challenging in order to question and open up how the interactions between diverse individuals, groups and organizations evolve and shape wayang kulit for international appreciation and local tasks. Wayang kulit is performed in the court, in rural areas and in museum for tourism promotion, it is used for business and political purposes while its aesthetic is borrowed by visual and performance artists. This makes the boundaries between what can be considered traditional and contemporary wayang continuously blurred; the same can be argued in relation to the global and the local dynamics of art and heritage formation that are also continuously blurred.

The peculiarity of DIY as the designation itself suggests is in term of its decisional autonomy e authority, a separate administrative entity as recently the law reaffirmed through Undang-Undang № 13/2012, concerning the privilege of Yogyakarta (Keistimewaan Daerah Istimewa Yogyakarta) and reinforced by the Regulation of the Special Region of Yogyakarta (Peraturan Daerah Istimewa Yogyakarta) № 1/2013, on the Authority in Privileged Affairs (Kewenangan Dalam Urusan Keistimewaan). Its distinctiveness is also known for the Special Region of Yogyakarta being a center of classical Javanese fine art and culture. It is reflected in cultural realities and politics, aiming for a dynamic and creative region especially for what concern culture, education and tourism. However its transisi situation and multidimensi character is also often stressed as at the meeting "Peran Komunitas Budaya di Era Keistimewaan DIY" (Role of Community Culture in the Age of the privilege of Yogyakarta) held on August 2-3, 2016 at Yogyakarta.

Places and ways of living are continuously shaped and affected by politics as it is tangible with Desa Budaya and Desa Wisata national program. So far, there are 42 cultural villages across the four regencies (kabupaten Bantul, Gunung Kidul, Kulon Progo and Sleman) and the city (kota Yogyakarta) that constitute DIY. DIY and Bali were appointed by the Indonesian Ministry of Foreign Affairs as ambassadors for cultural diplomacy thus the cultural village as the front guard and the cutting edge in preserving the culture (http://nasional.republika.co.id/ berita/nasional/daerah/16/04/05/o55zc5382-kulon-progo-dan- gunung-kidul-jadipusat-percontohan-desa-budaya).

Despite being emphasized a synergy with the local community, most of the initiatives for developing the cultural villages came from dinas, the local 
governmental department, as well the funding. In some cases what is called gotong royong mutual assistance between villagers play an important role too. Anyway the law Undang-Undang № 23/2014 requires the grantee for tourist village shall be a legal entity. Almost all of the initiatives in tourist village in the province of DIY have not legal status. Some have the status of village-owned enterprises, Badan Usaha Milik Desa (BUMDes), but the status BUMDes still unable to receive the grant because the Ministerial Regulation № 4/2015 on the establishment, management and dissolution of BUMDes failed to provide clear and specific guidelines regarding the ownership and management of village assets. These cultural initiatives and politics reflect dynamics between local, national and global dimension. In a certain way they are indicative of an imaginary design for the future.

To think about how life is in specific times and places, how might or could be like, is or ideally should be the aim of doing anthropology and therefore the utopic aim to strive for in each meeting and discussion along this research.

Trying to do so I use the drawing as also a learning practice. Drawing has all to do with the way one observe and imply a real and deep engagement with the surroundings. In a certain way the practice is also transformational, it changes the way to look at so the way to be in relation with it, to correspond to the world.

Drawing as ethnographic instrument however occupied various roles in the history of anthropological methods. For some authors it was indispensable for thinking and describing sociocultural realities, especially the invisible one. For some others drawing was ignored or relegated to a minor or subsidiary role in the fieldwork, if compared with other methods based on writings or words such as interviews, questionnaires, family stories, biographies and so on. Recently anyway drawings regained a certain prominence in the ethnographic practices (Afonso, 2004), as for example in urban contexts (Kuschnir, 2011) and in the imaginative logic of discovery (Taussig, 2011).

In my experience turned out to be not entirely compatible the idea to draw at the same time of conversations. Probably it can sound trivial, but apparently it wasn't at least for me at the time I was projecting myself in the fieldwork. I imagined myself talking to people and at the same time to draw their portrait. With time and some initial frustration I realized it was not possible in the way I want it. Drawing and discussing, both practices each in its own way, are engagement with, correspondence, sharing and cannot be done at the same time or better said I am not able to. I need to halt one of the activities to be fully committed to the other as also my interlocutor often stops his or her activity for corresponding.

"Anyway I appreciated that you were learning making wayang, instead of just reading about it" one of my puppet maker colleagues with a master degree in forestry said to me at the closing ceremony. Finally someone revealed to me to be aware of my approach with wayang. "With hand into the mass" along the research I realized that the process of the research itself constitutes a creative doing and practical understanding where object, subject and process became all 
in one. Borrowing a performance studies' expression, it is a kind of "performing fieldwork", a dialog between anthropology and art in which objects are subjects are practices and in which learning is transforming the way to be in life.

\section{REFERENCES}

Afonso, Ana Isabel. (2004), "New graphics for old stories. Representation of local memories through drawings" (with drawings by Manuel João Ramos) in PINK, Sarah, Kurti LÁSZLÓ and Ana Isabel AFONSO (eds.), Working Images. Visual Research and Representation in Ethnography, pp. 72-89, New York: Routledge.

Andrieu, Sarah Anaïs. (2009), "Heritage and Paradox", Inside Indonesia, no 97, JulSep, in<http://www.insideindonesia.org/weekly-articles/heritage-and-paradox> (consultedonNovember 14, 2014).

Appadurai, Arjun. (1986), The social life of things: Commodities in cultural perspective, Cambridge: Cambridge University Press.

Banks, Marcus and Howard Morphy, eds. (1997), Rethinking Visual Anthropology, New Haven: Yale University Press.

Bateson, Gregory and Margaret Mead. (1942), Balinese Character: A Photographic Analysis, New York, New York Academy of Science.

Boonstra, Sadiah. (2014), Changing Wayang Scenes: Heritage Formation and Wayang Performance Practice in Colonial and Postcolonial Indonesia, Amsterdam: VU University.

ClifforD, James. (1988), "On Ethnographic Authority" in The Predicament of Culture. Twentieth Century Ethnography, Literature and Art, pp. 21-54, Cambridge: MA.

Enwezor, Okwui. (2008), Archive Fever: uses of Document in Contemporary Art, Gottingen, Steidl, New York: International Center of Photography.

Foster, H. (1996), The Artist as Ethnographer, The return of the real: The Avant-Garde at the end of the century, Cambridge: MIT Press.

Gell, Alfred. (1998), Art and Agency: an Anthropological Theory, Oxford: Clarendon Press.

Grimshaw, Anna. (2001), The Ethnographer's Eye: Ways of Seeing in Modern Anthropology, Cambridge: Cambridge University Press.

Ingold, Tim. (2011), Being Alive: Essays on Movement, Knowledge and Description, London and New York: Routledge.

Ingold, Tim. (2013), Making. Anthropology, archaeology, art and architecture, London and New York: Routledge.

Kuschnir. K., 2011, “Drawing the City. A Proposal for an Ethnographic Study in Rio de Janeiro", Vibrant, V.8 No. 2, pp. 609-642.

MacDougall, David (1998), Transcultural Cinema, Princeton University Press.

Morphy, H.; Perkins, M. (eds.), 2006, Anthropology of art: a reader, Oxford, Blackwell.

Mrazék, Jan (2008), “Ways of Experiencing Art: Art History, Television, and Javanese Wayang" in MRAZÉK, Jan and PITELKA, Morgan (eds.), What's the Use of Art?, pp. 272-304, Honolulu, University of Hawaii Press.

Pink, Sarah. (2004), "Situating visual research" in PINK, Sarah, Kurti László and Ana Isabel Afonso (eds.), Working Images. Visual Research and Representation in Ethnography, New York: Routledge.

Schechner, Richard. (2002), Performance Studies: An introduction, London, New York: Routledge.

Schneider, Arnd and Christopher Wright, eds. (2010), Between Art and Anthropology: Contemporary Ethnographic Practice, Oxford: Berg.

Smith, Laurajane. (2006), Uses of Heritage, London, New York: Routledge.

Taussig, Michael. (2011), I Swear I Saw This: Drawings In Fieldwork Notebooks, Namely My Own, Chicago: University of Chicago Press. 